\title{
KEBEBASAN BERKONTRAK TERHADAP PERJANJIAN STANDAR BAKU DALAM MENCAPAI KEADILAN BERKONTRAK
}

\author{
Wiwin Widiyaningsih ${ }^{1}$ \\ Email : notwin85@yahoo.com
}

\begin{abstract}
ABSTRAK
Asas kebebasan berkontrak merupakan asas yang dipergunakannya sebagai landasan keberadaan perjanjian baku dalam mengatur hubungan hukum antara pelaku usaha dengan konsumen, namun dalam kenyataannya sangat jarang para pihak yang mengadakan perjanjian mempunyai posisi tawar seimbang. Tujuan penelitian ini untuk mengetahui penerapan asas kebebasan berkontrak dalam mewujudkan keadilan para pihak dan untuk mengetahui kedudukan perjanjian baku agar dapat mencapai keadilan bagi kedua belah pihak. Metode penelitian ini menggunakan pendekatan yuridis normatif dengan spesifikasi penelitian bersifat deskriptif analitis. Hasil penelitian menunjukkan bahwa asas kebebasan berkontrak dalam pelaksanaan perjanjian baku seringkali menjadi alasan pembenar bagi pelaku usaha kepada konsumen sehingga menimbulkan ketidakadilan. Adanya ketidakseimbangan kedudukan pelaku usaha dengan konsumen menyebabkan ketentuan-ketentuan dalam perjanjian baku lebih menguntungkan pelaku usaha dan merugikan konsumen. Oleh karena itu diperlukan pembatasan penerapan asas kebebasan berkontrak dalam kontrak baku dengan memberlakukan aturan yang melarang beberapa klausul tertentu untuk dimasukkan dalam kontrak baku, serta melakukan pengawasan terhadap penggunaan kontrak baku dalam kegiatan bisnis.
\end{abstract}

Kata Kunci : Kebebasan Berkontrak, Perjanjian Baku, Keadilan.

\footnotetext{
${ }^{1}$ Dosen Fakultas Hukum Universitas Majalengka
} 


\section{A. Latar Belakang}

Suatu perjanjian melahirkan akibat hukum berupa hak dan kewajiban. Sesuatu yang merupakan hak bagi suatu pihak dalam perjanjian akan menjadi kewajiban bagi pihak lain. Saat ini ketentuan hukum perjanjian yang banyak digunakan di Indonesia adalah ketentuan-ketentuan Buku III KUHPerdata tentang Perikatan. Salah satu asas utama yang melandasi hukum perjanjian adalah asas kebebasan berkontrak.

Asas kebebasan berkontrak (partij autonomi, freedom of kontrak, contract vrijheid) yang mengakibatkan sistem hukum perjanjian terbuka. Peraturan-peraturannya bersifat melengkapi (aanvullen, regulatory). Kebebasan berkontrak artinya bebas menentukan isi perjanjian dan dengan siapa mengadahkan perjanjian. Asas kebebasan berkontrak bersifat universal yang merunjuk pada adanya kehendak yang bebas dari setiap orang untuk membuat kontrak atau tidak membuat kontrak, pembatasannya hanyalah untuk kepentingan umum dan di dalam kontrak itu harus ada keseimbangan yang wajar. Satu hal yang patut diperhatikan, bahwa asas kebebasan berkontrak adalah mengasumsikan ada posisi tawar yang seimbang diantara para pembuat kontrak. $^{2}$ Keseimbangan tersebut baik secara ekonomi maupun sosial. ${ }^{3}$

Asas kebebasan berkontrak ini diakui dalam hukum perjanjian di Indonesia, sehingga hukum perjanjian di Indonesia menganut sistem terbuka. Artinya, hukum tidak hanya mengakui jenis-jenis perjanjian yang diatur dan

\footnotetext{
${ }^{2}$ M Faiz mufidi, Perjanjian Alih Teknologi Dalam Bisnis Frenchise sebagai Sarana Pengenbangan Hukum Ekonomi, Disertasi Doktor, Universitas Padjajaran, Bandung, 2008 hlm.12

${ }^{3}$ Ridwan Khairandy, Itikad Baik dalam Kebebasan Berkontrak, Universitas Indonesia , Fakultas Hukum, Pascasarjana, 2003, hlm.124
} 
diberi nama dalam undang-undang tetapi juga mengakui dan memberikan akibat terhadap perjanjian yang dibuat para pihak sekalipun jenis perjanjian tersebut tidak diatur dalam undang-undang. Hal ini dapat disimpulkan dari ketentuan Pasal 1338 ayat (1) KUHPerdata. ${ }^{4}$ Namun dalam kenyataannya sangat jarang para pihak yang mengadakan perjanjian mempunyai posisi tawar seimbang. Pada perjanjian yang demikian, pihak yang mempunyai posisi tawar lebih kuat akan lebih menentukan isi perjanjian.

Perjanjian-perjanjian yang paling menyolok menunjukkan dominan salah satu pihak adalah perjanjian yang dalam bahasa Belanda disebut standard voorwarden atau dalam hukum Inggris disebut standard contract. $^{5}$ Di Indonesia ada yang menyebut sebagai perjanjian baku. Pada perjanjian ini ketentuan-ketentuan di dalamnya lebih banyak ditentukan oleh pihak yang mempunyai posisi tawar lebih kuat dibandingkan pihak lainnya. ${ }^{6}$ Sedangkan pihak yang posisi tawarnya lebih rendah, sangat kecil kemungkinannya mengadakan perubahan terhadap ketentuan-ketentuan yang terdapat dalam draft perjanjian. Dalam arti pihak yang menerima penawaran tidak dalam posisi memilih dari pilihan yang luas tetapi hanya memilih untuk menerima atau menolak tawaran tersebut. ${ }^{7}$

Pada mulanya penggunaan perjanjian baku didasari pertimbangan ekonomis, yaitu untuk mengurangi biaya yang ditimbulkan oleh pembuatan

\footnotetext{
${ }^{4}$ Lina Jamilah, Asas Kebebasan Berkontrak Dalam Perjanjian Standar Baku, Jurnal Ilmu Hukum, Syiar Hukum, Fh.Unisba. Vol. Xiii. No. 1 Maret - Agustus 2012, hlm. 229 46.

${ }^{5}$ Mariam Darus Badrulzaman, Aneka Hukum Bisnis, Alumni, Bandung, 1994, hlm.

${ }^{6}$ Ibid

${ }^{7}$ M Faiz Mufidi, Op.Cit, hlm. 13
} 
kontrak dan juga untuk kepraktisan. ${ }^{8}$ Oleh karena itu, dewasa ini perjanjian baku dipergunakan tidak hanya dalam Perbankan konvensional, Perbankan syariah, Pasar modal syariah, Asuransi syariah, akan tetapi perjanjian baku banyak diperggunakan dalam berbagai transaksi perdagangan yang meliputi penjualan barang, jasa maupun piranti lunak, termasuk lisensi. ${ }^{9}$

Dengan banyaknya perjanjian baku dipergunakan dalam berbagai transaksi dan melihat dalam perjanjian tersebut, dimana posisi dominan oleh satu pihak, maka ada kemungkinan perjanjian baku tersebut, telah mengurangi perwujudan asas kebebasan berkontrak dalam perspektif perlindungan yang seimbang bagi para pihak dan bertentangan dengan rasa keadilan.

Patut diduga sifat perjanjian yang berbentuk baku ini tidak akan mampu memberikan rasa keadilan yang memadai bagi pihak yang posisinya lemah. Keadilan dalam hal ini adalah keadilan yang didasari Asas Proporsionalitas, di mana para pihak mempunyai beban kewajiban dan hak yang proporsional dengan kontribusinya. ${ }^{10}$ Namun dalam kenyataanya bentuk maupun isi perjanjian telah ditentukan oleh pihak yang kuat sebelum perjanjian itu ditandatangani oleh para pihak. Tidak akan bisa dipungkiri pihak yang kuat akan berusaha agar semua kepentingannya dapat diakomodir di dalam

\footnotetext{
${ }^{8}$ Ibid

${ }^{9}$ Tim Lindsey, et.al. Hak Kekayaan Intelektual Suatu Pengantar, Asian Law Group bekerjasama dengan PT Alumni, Bandung, 2003, hlm. 333

10 Hernoko, A Yudha \& Ratnawati, Ika Yunia, Asas Proporsionalitas dalam Perjanjian Waralaba (Franchise). Jurnal Hukum Bisnis, Vol. 1 No.1, April 2015, hlm 17
} 
perjanjian tersebut, meskipun hal tersebut potensial untuk menimbulkan kerugian ekonomi atau ketidakadilan pada pihak lainnya ${ }^{11}$

Adanya perbedaaan posisi bagi para pihak ketika perjanjian baku diadakan tidak memberikan kepada pihak konsumen dalam mengadahkan perundingan dengan pelaku usaha. Dalam hal ini, konsumen tidak diberikan keleluasan dalam menentukan isi perjanjian karena konsumen tidak mempunyai kewenangan. Sehingga perjanjian baku dinilai tidak memenuhi aturan yang dikehendaki oleh Pasal 1320 KUH Perdata jo. Pasal 1338 KUH Perdata. $^{12}$

Berpijak pada permasalahan tersebut, maka dapat diketahui bahwa di dalam perjanjian baku yang dibuat, terdapat unsur keharusan yang harus dilakukan oleh salah satu pihak dalam rangka pemenuhan atas aturan yang ada di dalam perjanjian tersebut. Merujuk pada landasan dasar dilakukanya suatu kontrak atau perjanjian, dalam hal ini cenderung mengacu pada hal-hal yang bersifat bisnis atau ekonomi (keuangan). Oleh karena itu dalam suatu kontrak yang dibuat oleh para pihak, seharusnya mampu mewadahi kepentingankepentian para pihak. Adanya kepentingan para pihak, merupakan suatu hal yang tidak dapat dipisahkan, karena pada dasarnya dalam kontrak perjanjian yang dilakukan para pihak di dalamnya sama-sama memiliki kepentingan.

Mengacu pada pemikiran bahwa suatu perjanjian terjadi ketika para pihak yang ada di dalamnya sepakat untuk saling mengikatkan diri, maka

${ }^{11}$ Ery Agus Priyono, Aspek Keadilan Dalam Kontrak Bisnis Di Indonesia (Kajian pada Perjanjian Waralaba ) Jurnal Law Reform Program Studi Magister Ilmu Hukum, Fakultas Hukum Universitas Diponegoro, Volume 14, Nomor 1, Semarang 2018, hlm 17

${ }^{12}$ Mariam Darus Badrulzaman, Aneka Hukum ... Op.Cit, hlm. 105. 
dalam hal ini pelaksanaan perjanjian tidak dapat lepas dari prinsip konsensualisme yang merupakan suatu syarat pembentuk perjanjian. Prinsip konsensualisme merupakan syarat mutlak dalam setiap kontrak yang berfungsi untuk menjamin kepastian hukum. ${ }^{13}$

Suatu perjanjian dianggap terjadi setelah para pihak mengatakan kesepakatan. Lebih jauh memahami tentang kesepakatan para pihak, bahwa pada hakikatnya dalam hubungan hukum perjanjian, kesepakatan yang terjadi terbentuk karena proses tawar menawar. ${ }^{14}$ Melalui proses tawar menawar inilah para pihak akan mengetahui secara jelas dan detail terkait dengan hak serta kewajiban yang harus dilaksanakan dalam menjalankan perjanjian tersebut.

Dalam perjanjian baku yang isinya telah ditentukan oleh salah satu pihak, maka prinsip-prinsip hukum perjanjian yang terdapat di dalam hukum perjanjian seakan terabaikan, hal ini dapat dilihat dari tidak adanya negosiasi dalam perjanjian baku, posisi tawar salah satu pihak juga lemah. ${ }^{15}$ Posisi demikian yang menjadi ketertarikan penulis untuk melakukan penelitian dengan judul “Asas Kebebasan Berkontrak Terhadap Perjanjian Standar

\section{Baku Dalam Mencapai Keadilan Berkontrak"}

${ }^{13}$ R. Subekti, Aspek-Aspek Hukum Perikatan Nasional, Alumni, Bandung,1986. hlm 5. Lihat juga Yohanes Sogar Simamora, Hukum Perjanjian, LaksBang PRESSindo, Yogyakarta, 2009, hlm. 191

${ }^{14}$ Ibid

15 Muhamad Hasan Muaziz dan Achmad Busro, Pengaturan Klausula Baku Dalam Hukum Perjanjian Untuk Mencapai Keadilan Berkontrak, Jurnal Law Reform Program Studi Magister Ilmu Hukum, Fakultas Hukum Universitas Diponegoro, Volume 11, Nomor 1, Tahun 2015, hlm76 


\section{B. Identifikasi Masalah}

Berdasarkan uraian di atas, pokok permasalahan yang akan dibahas dalam jurnal ini adalah sebagai berikut:

1. Bagaimana penerapan asas kebebasan berkontrak dalam mewujudkan keadilan para pihak?

2. Bagaimana kedudukan perjanjian baku agar dapat mencapai keadilan bagi kedua belah pihak?

\section{Tujuan Penelitian}

Sesuai dengan permasalahan di atas, maka tujuan penelitian ini adalah:

1. Untuk mengetahui penerapan asas kebebasan berkontrak dalam mewujudkan keadilan para pihak

2. Untuk mengetahui kedudukan perjanjian baku agar dapat mencapai keadilan bagi kedua belah pihak.

\section{Kerangka Pemikiran}

Kerangka teori adalah kerangka pemikiran atau butir-butir pendapat mengenai suatu permasalahan yang dapat dijadikan sebagai pedoman (guidance) teoritis untuk dijadikan sebagai pisau analisis dalam jurnal ini. Kerangka teori ${ }^{16}$ yang dimaksudkan untuk memberikan gambaran ataupun batasan-batasan tentang teori-teori yang akan dipakai sebagai landasan penelitian yang akan dilakukan. ${ }^{17}$ Menurut John. W. Best, teori pada dasarnya

\footnotetext{
${ }^{16}$ Uber Silalahi, Metode dan Metodologi Penelitian. Bina Budaya, Bandung 1998, hlm. 69

17 Mardalis, Metode Penelitian (Suatu Pendekatan Proposal), Bumi Aksara. Jakarta, 1999, hlm. 41
} 
berisi penggambaran hubungan sebab akibat diantara variabel-variabel. Suatu teori di dalam dirinya terkandung keunggulan untuk bisa menjelaskan suatu gejala. Tidak itu saja, suatu teori juga berkekuatan untuk memprediksi sesuatu gejala. ${ }^{18}$ Teori adalah "Something assume as starting point scientific investigation" Asumsi dasar untuk membuktikan penelitian ilmiah. ${ }^{19}$ Teori di jadikan prinsip umum yang tingkat kebenarannya menjadi rujukan dan di akui kalangan ilmuan. ${ }^{20}$ Teori hukum adalah teori dalam bidang hukum yaitu berfungsi memberikan argumentasi yang meyakinkan bahwa hal-hal yang di jelaskan itu adalah ilmiah atau paling tidak memberikan gambaran bahwa halhal yang dijelaskan itu memenuhi standar teoritis, ${ }^{21}$ berisikan teori yang dapat membantu peneliti dalam menentukan tujuan dan arah penelitian, serta berguna untuk menentukan konsep secara tepat. ${ }^{22}$

Sehubungan dengan permasalahan yang telah diuraikan di atas, maka kerangka pemikiran penelitian ini menggunakan Teori keseimbangan, serta didukung dengan Teori Perjanjian dan Teori Keadilan .

Teori yang digunakan sebagai pisau analisis dalam penelitian ini, yaitu yang pertama teori keseimbangan, Teori ini memberikan rujukan asas-asas yang dipakai dalam pembuatan perjanjian/kontrak baku agar dapat memberikan keadilan terhadap para pihak sehingga mampu melindungi hak asasi manusia.

\footnotetext{
${ }^{18}$ Ibid. hal. 41-42.

${ }^{19}$ Paul Edward, disitir oleh juhaya S. Praja, Teori Hukum Dan Aplikasinya. Pustaka Setia, Bandung, 2011, hlm 1.

${ }^{20}$ Ibid

${ }^{21}$ Ismail Sunny, dan Muhammad Rasyid, Negara Hukum (Suatu Study Tentang Suatu Prinsip-prinsipnya Dilihat Dari Segi Hukum Islam, Implementasinya Pada Periode Negara Madinah Dan Masa Kini), Kencana Prenada Media Group, Jakarta,2010, hlm. 8.

${ }^{22}$ Koentjaraningrat, Metode-metode Penelitian Masyarakat, Edisi Ketiga, Gramedia, Jakarta, 1993, hlm 19
} 
Teori ini dikemukakan oleh Joel Levin dan Banks Mc.Dowell dengan awal thesis landasan kekuatan mengikatnya kontrak adalah "A legally binding contract exists where an obligation has been voluntarily assumed, is reasonably fair to the party against whom it is enforced, is consistent with society"s contractual expectations, and gives rise to no administrative difficulties barring enforcement"'(sebuah kontrak memiliki kekuatan mengikat secara hukum apabila kewajiban yang timbul secara sukarela, adil bagi pihak yang lainnya, konsisten dengan harapan-harapan masyarakat dalan hubungan kontraktual, dan tidak memiliki kesulitan administrasi dalam pelaksanaannya) ${ }^{23}$ Komponen kontrak yang dapat mengikat secara hukum terdiri dari empat komponen yakni:

1. Dilakukan secara sukarela (voluntariness);

2. keadilan/kelayakan (fairness),

3. harapan-harapan hubungan kontraktual dalam masyarakat/ketertiban umum (society"s contractual expectations);

4. tidak ada kesulitan adminsitrasi dalam pelaksanaannya (absence of administrative difficulties).

Komponen teori pertama dan kedua yakni "dilakukan secara sukarela (kesukarelaan)" dan "keadilan" merupakan variabel yang berubah-ubah namun bersifat "check and balance" artinya dalam suatu kontrak apabila tingkat kesukarelaannya kurang maka secara proporsional keadilan harus ditingkatkan,

${ }^{23}$ Joel Levin and Banks McDowell, "The Balance Theory of Contracts: Seeking Justice in Voluntary Obligations", Articles, sumber:http://lawjournal.mcgill.ca/userfiles/othermcdowell.pdf, diakses pada tanggal 12/0 2020. 
demikian pula sebaliknya apabila tingkat kesukarelaannya tinggi maka penekanan pada tingkat keadilan menjadi lebih berkurang.

Kesukarelaan (voluntariness) diukur berdasarkan tindakan yang dilakukan secara sadar (consciously) dan dipilih berdasarkan kehendak bebas (willingly) dari pemberi janji. Semakin tinggi tingkat kesukarelaan maka semakin besar kekuatan berlakunya yang dapat dipaksakan oleh hukum untuk berlakunya. Kontrak yang di dalamnya tidak terdapat pilihan bebas (tidak ada pilihan lain) tidak memiliki kekuatan hukum yang mengikat, sehingga menimbulkan kebutuhan akan "keadilan/kelayakan” di dalamnya.

Keadilan atau kelayakan (fairness) adalah sebuah konsep moral yang menjadi perdebatan sejak dahulu. Berdasarkan teori ini konsep keadilan/kelayakan (fairness) ditandai dengan adanya pengetahuan yang cukup terhadap semua aspek dari kontrak dan memiliki kemampuan untuk memperhitungkan akibat dari kontrak $^{24}$. Penekanannya pada hal-hal yang secara wajar akan disepakati oleh para pihak berdasarkan pengetahuannya bukan pada persamaan hasil yang akan diharapkan (proporsional). Pengetahuan yang penuh oleh para pihak terhadap hal-hal yang disyaratkan dalam kontrak.

Komponen ketiga dan keempat yakni sesuai dengan ketertiban umum (consistency with society"s contractual expectations) ${ }^{25}$ dan tidak ada kesulitan

\footnotetext{
${ }^{24}$ Sinta, Kajian Teoritik Kontrak Baku, https://sinta. unud.ac.id/uploads/ dokumen_dir/28b180 cebdadda3a7ae54c3df73da611.pdf, diakses pada tanggal 9/2/2020

${ }^{25}$ Peter Mahmud Marzuki menyatakan bahwa ketertiban umum yang dibuat untuk membatasi kebebasan berkontrak tidak harus dalam ruang lingkup hukum publik namun terdapat pula dalam ruang lingkup hukum privat, ketertiban umum tidak harus selalu berupa aturan hukum yang bersifat memaksa, melainkan dapat pula berupa asas-asas hukum. Suatu
} 
administratif (administrative convenience) dalam pelaksanaanya merupakan variable yang tergantung pada undang-undang dan bersifat relatif. Kesulitan administratif diartikan tidak menimbulkan kesulitan dalam pelaksanaanya contohnya penentuan ganti rugi yang jelas dan dapat diukur.

Sebagai pendukung teori keseimbangan akan digunakan teori Perjanjian. Istilah perjanjian sering disebut juga dengan persetujuan, yang berasal dari bahasa Belanda yakni overeenkomst. Menurut Subekti "Suatu perjanjian dinamakan juga persetujuan karena kedua pihak itu setuju untuk melakukan sesuatu, dapat dikatakan bahwa dua perkataan (perjanjian dan persetujuan) itu adalah sama artinya", ${ }^{26}$

Istilah kontrak merupakan istilah yang dipakai dalam praktek bisnis selain istilah perjanjian dan persetujuan. Kerancuan akan istilah kontrak atau perjanjian masih sering diketemukan dalam praktek bisnis. Pelaku bisnis memahami bahwa kedua istilah antara perjanjian dan kontrak mempunyai pengertian yang berbeda. Menurut Muhammad Syaifuddin pengertian antara perjanjian dan kontrak adalah sama, jika dilihat dari pengertian yang terdapat dalam KUHPerdata sebagai produk warisan kolonial Belanda, maka ditemukan istilah "overeenkomst" dan "contract" untuk pengertian yang sama, sebagaimana dicermati dalam Buku III Titel Kedua Tentang PerikatanPerikatan yang Lahir dari Kontrak atau Persetujuan, yang dalam bahasa

kontrak bertentangan dengan ketertiban umum apabila bertentangan dengan asas yang fundamental dari organisasi kehidupan bermasyarakat yang ada. Asas-asas fundamental merupakan nilai-nilai filosofis dari kehidupan bernegara dan bermasyarakat. (Lihat Peter Mahmud Marzuki, "Batas-Batas Kebebasan Berkontrak", Artikel, Majalah Yuridika Volume 18 No.3, 2003, hlm 215)

${ }^{26}$ Subekti, Hukum Perjanjian, Intermassa, Jakarta, 1987, hlm.11 
Belanda ditulis "Van verbintenissen die uit contract of overeenkomst geboren worden".

Definisi dari perjanjian diatur dalam Pasal 1313 KUHPerdata yang menentukan bahwa "Suatu persetujuan adalah suatu perbuatan di mana satu orang atau lebih mengikatkan diri terhadap satu orang lain atau lebih". Dari definisi tersebut beberapa sarjana kurang menyetujui karena mengandung beberapa kelemahan.

Menurut Abdulkadir Muhammad, rumusan Pasal 1313 KUHPerdata mengandung kelemahan karena: ${ }^{27}$

1. Hanya menyangkut sepihak saja.

Dapat dilihat dari rumusan "satu orang atau lebih mengikatkan dirinya terhadap satu orang atau lebih lainnya". Kata "mengikat" sifatnya sepihak, sehingga perlu dirumuskan "kedua belah pihak saling mengikatkan diri", dengan demikian terlihat adanya konsensus antara pihak-pihak, agar meliputi perjanjian timbal balik.

2. Kata "perbuatan" termasuk di dalamnya konsensus.

Pengertian perbuatan termasuk juga tindakan melaksanakan tugas tanpa kuasa atau tindakan melawan hukum yang tidak mengandung consensus. Seharusnya digunakan kata persetujuan

3. Pengertian perjanjian terlalu luas

Luas lingkupnya juga mencangkup mengenai urusan janji kawin yang termasuk dalam lingkup hukum keluarga, seharusnya yang diatur adalah

\footnotetext{
${ }^{27}$ Abdulkadir Muhamad, Hukum Perikatan, Citra Aditya Bandung, 1992,hlm.78.
} 
hubungan antara debitur dan kreditur dalam lapangan harta kekayaan. Perjanjian yang dimaksudkan di dalam Pasal 1313 KUHPerdata adalah perjanijan yang berakibat di dalam lapangan harta kekayaan, sehingga perjanjian di luar lapangan hukum tersebut bukan merupakan lingkup perjanjian yang dimaksudkan.

4. Tanpa menyebutkan tujuan.

Rumusan Pasal 1313 KUHPerdata tidak mencantumkan tujuan dilaksanakannya suatu perjanjian, sehingga pihak-pihak yang mengikatkan diri tidak memiliki kejelasan untuk maksud apa diadakan perjanjian.

Pendapat dari Abdul Kadir Muhamad didukung oleh pendapat R. Setiawan. Menurutnya bahwa "Pengertian perjanjian tersebut terlalu luas, karena istilah perbuatan yang dipakai dapat mencakup juga perbuatan melawan hukum dan perwalian sukarela, padahal yang dimaksud adalah perbuatan melawan hukum". ${ }^{28}$ Mariam Darus Badrulzaman ${ }^{29}$, tidak memberikan penjelasan mengenai apa itu perjanjian, namun memberikan kritik pula terhadap definisi perjanjian yang terdapat di dalam ketentuan Pasal 1313 KUHPerdata adalah tidak lengkap dan terlalu luas. Tidak lengkap karena hanya mengenai perjanjian sepihak saja, sedangkan terlalu luas karena mencakup juga janji kawin yaitu perbuatan di dalam hukum keluarga yang menimbulkan perjanjian juga.

Penelitian ini juga mengunakan teori keadilan untuk mengatur kontrak standar baku. Pembahasan tentang hubungan kontraktual para pihak pada

\footnotetext{
${ }^{28}$ R.Setiawan, Pokok-Pokok Hukum Perikatan, Bina Cipta, Bandung, 1979, hlm.49.

${ }^{29}$.Mariam Darus Badrulzaman, Aneka Hukum ..Op.Cit, hlm.18
} 
hakikatnya tidak dapat dilepaskan dalam hubungannya dengan masalah keadilan. Kontrak sebagai wadah yang mempertemukan kepentingan satu pihak dengan pihak lain menuntut bentuk pertukaran kepentingan yang adil. Pertanyaan seputar apa itu "keadilan" adalah sebuah pertanyaan yang acap kali kita dengar, namun pemahaman yang tepat justru rumit bahkan abstrak, terlebih apabila dikaitkan dengan pelbagai kepentingan yang demikian kompleks. ${ }^{30}$ Keadilan menurut Aristoteles, ${ }^{31}$ dalam karyanya "Nichomachean ethics", artinya berbuat kebajikan, atau dengan kata lain, keadilan adalah kebajikan yang utama. Menurut Aristoteles, ${ }^{32}$ "justice consists in treating equals equally and unequals unequally, in proportion to their inequality." Prinsip ini beranjak dari asumsi "untuk hal-hal yang sama diperlakukan secara sama, dan yang tidak sama juga diperlakukan tidak sama, secara proporsional." Ulpianus ${ }^{33}$ menggambarkan keadilan sebagai "justitia est constans et perpetua voluntas ius suum cuique tribuendi" (keadilan adalah kehendak yang terus-menerus dan tetap memberikan kepada masing-masing apa yang menjadi haknya) atau "tribuere cuique suum" - "to give everybody his own", memberikan kepada setiap orang yang menjadi haknya. ${ }^{34}$ Perumusan ini dengan tegas mengakui hak masing-masing person terhadap lainnya serta apa yang seharusnya menjadi bagiannya, demikian pula sebaliknya.

\footnotetext{
${ }^{30}$ Burhanuddin Salam, Etika Sosial, Rineka Cipta, Jakarta, 1997, hlm. 117.

${ }^{31}$ Ibid

${ }^{32}$ O. Notohamidjojo, Masalah: Keadilan, Tirta Amerta, Semarang, 1971, hlm. 7.

${ }^{33}$ O. Notohamidjojo, Op. Cit., hlm. 18-19.

${ }^{34}$ K. Bertens, Pengantar Etika Bisnis, Kanisius, Yogjakarta, 2000, hlm. 86-87.
} 
Menurut Thomas Aquinas ${ }^{35}$ Dalam konteks keadilan distributif, keadilan dan kepatutan (equity) tidak tercapai semata-mata dengan penetapan nilai yang aktual, melainkan juga atas dasar kesamaan antara satu hal dengan hal yang lainnya (aequalitas rei ad rem). Ada dua bentuk kesamaan yaitu:

1. Kesamaan proporsional (acqualitas proportionis)

2. Kesamaan kuantitas atau jumlah (acqualitas quantitas)

Sementara itu pembagian keadilan menurut pengarang modern, antara lain sebagaimana yang dilakukan oleh John Boatright dan Manuel Velasquez, ${ }^{36}$ yaitu:

1. Keadilan distributif (distributive justice), mempunyai pengertian yang sama pada pola tradisional, di mana benefits and burdens harus dibagi secara adil,

2. Keadilan retributif (retributive justice), berkaitan dengan terjadinya kesalahan, di mana hukum atau denda dibebankan kepada orang yang bersalah haruslah bersifat adil,

3. Keadilan kompensatoris (compensatory justice), menyangkut juga kesalahan yang dilakukan, tetapi menurut aspek lain, di mana orang mempunyai kewajiban moral untuk memberikan kompensasi atau ganti rugi kepada pihak lain yang dirugikan

Sehubungan dengan hakikat keadilan dalam kontrak, beberapa sarjana mengajukan pemikirannya tentang keadilan yang berbasis kontrak, antara lain

${ }^{35}$ E. Sumaryono, Etika Hukum Relevansi Teori Hukum Kodrat Thomas Aquinas, Kanisius, Yogyakarta, 2002, hlm. 90-91

${ }^{36}$ Ibid 
John Locke, Rosseau, Immanuel Kant, serta John Rawls. ${ }^{37}$ Para pemikir tersebut menyadari bahwa tanpa kontrak serta hak dan kewajiban yang ditimbulkannya, maka masyarakat bisnis tidak akan berjalan. Oleh karena itu tanpa adanya kontrak, orang tidak akan bersedia terikat dan bergantung pada pernyataan pihak lain. Kontrak memberikan sebuah cara dalam menjamin bahwa masing-masing individu akan memenuhi janjinya, dan selanjutnya hal ini memungkinkan terjadinya transaksi di antara mereka.

Dengan mengambil pelajaran dari kegagalan teori-teori sebelumnya, Rawls $^{38}$ mencoba menawarkan suatu bentuk penyelesaian yang terkait dengan problematika keadilan dengan membangun teori keadilan berbasis kontrak. Menurutnya suatu teori keadilan yang memadai harus dibentuk dengan pendekatan kontrak, di mana azas-azas keadilan yang dipilih bersama benarbenar merupakan hasil kesepakatan bersama dari semua person yang bebas, rasional, dan sederajat. Hanya melalui pendekatan kontrak sebuah teori keadilan mampu menjamin pelaksanaan hak dan sekaligus mendistribusikan kewajiban secara adil bagi semua orang. Oleh karenanya dengan tegas Rawls menyatakan, suatu konsep keadilan yang baik haruslah bersifat kontraktual, konsekuensinya setiap konsep keadilan yang tidak berbasis kontraktual harus dikesampingkan demi kepentingan keadilan itu sendiri.

37 Wacks, Raymond, Jurisprudence, Blackstone Press Limited, London, 1995. hlm. 191

$$
{ }^{38} \text { Ibid }
$$


Dalam konteks ini Rawls ${ }^{39}$ menyebut "justice as fairness" yang ditandai adanya prinsip rasionalitas, kebebasan dan kesamaan. ${ }^{40}$ Oleh karena itu diperlukan prinsip-prinsip keadilan yang lebih mengutamakan asas hak daripada asas manfaat. Rawls merumuskan dua prinsip keadilan distributif, sebagai berikut: ${ }^{41}$

1. Prinsip I - the greatest equal principle, bahwa setiap orang harus memiliki hak yang sama atas kebebasan dasar yang paling luas, seluas kebebasan yang sama bagi semua orang. Ini merupakan hal yang paling mendasar (hak asasi) yang harus dimiliki semua orang. Dengan kata lain, hanya dengan adanya jaminan kebebasan yang sama bagi semua orang maka keadilan akan terwujud (Prinsip Kesamaan Hak);

2. Prinsip II, ketidaksamaan sosial dan ekonomi harus diatur sedemikian rupa sehingga perlu diperhatikan asas atau prinsip berikut:

(1) (the different principle

(2) the principle of fair equality of opportunity.

Prinsip ini diharapkan memberikan keuntungan terbesar bagi orangorang yang kurang beruntung, serta memberikan penegasan bahwa dengan kondisi dan kesempatan yang sama, semua posisi dan jabatan harus terbuka bagi semua orang (Prinsip Perbedaan Objektif)

\footnotetext{
${ }^{39}$ Agus Yudha Hernoko, Keseimbangan Versus Keadilan Dalam Kontrak (Upaya Menata Struktur Hubungan Bisnis dalam Perspektif Kontrak yang Berkeadilan), Airlangga University Press,2010, hlm 10

${ }^{40}$ Andre Ata Ujan, Keadilan dan Demokrasi (Telaah Filsafat Politik John Rawls) Keadilan dan Demokrasi (Telaah Filsafat Politik John Rawls), Kanisius, Yogjakarta, 1999, hlm. 71.

${ }^{41}$ Agus Yudha Hernoko. Keseimbangan Versus...Op.Cit..hlm, 11
} 
Menarik untuk digarisbawahi bahwa konsep kesamaan menurut Rawls harus dipahami sebagai "kesetaraan kedudukan dan hak", bukan dalam arti "kesamaan hasil" yang dapat diperoleh semua orang. Kebebasan yang ada selalu dalam kebebasan yang "tersituasi" (dalam konteks "ini" dan "di sini"), sehingga disandarkan pada berbagai kondisi, keadaan-keadaan dan kualitas masing-masing. Tentunya pandangan ini semakin membuka mata mereka yang senantiasa menuntut hasil yang sama tanpa memandang proses (prosedur) dari awal hingga akhir. Bagi Rawls kesamaan hasil bukanlah alasan untuk membenarkan sebuah prosedur. Keadilan sebagai fairness atau sebagai pure procedure justice tidak menuntut setiap orang yang terlibat dan menempuh prosedur yang sama juga harus mendapat hasil yang sama. Sebaliknya, hasil prosedur yang fair itu harus diterima sebagai adil, juga apabila setiap orang tidak mendapat hasil yang sama. Dengan demikian konsep keadilan yang lahir dari suatu prosedur yang diterima oleh semua pihak juga harus diterima sebagai konsep yang pantas berlaku untuk umum. ${ }^{42}$ Oleh karena itu harus dipahami bahwa keadilan tidak selalu berarti semua orang harus selalu mendapatkan sesuatu dalam jumlah yang sama, tanpa memperhatikan perbedaan-perbedaan yang secara objektif ada pada setiap individu.

Terkait dengan kompleksitas hubungan kontraktual dalam dunia bisnis, khususnya terkait dengan keadilan dalam kontrak, maka berdasarkan pikiranpikiran tersebut di atas kita tidak boleh terpaku pada pembedaan keadilan klasik. Artinya analisis keadilan dalam kontrak harus memadukan konsep

${ }^{42}$ Andre Ata Ujan, Keadilan dan Demokrasi (Telaah Filsafat Politik John Rawls), Kanisius, Yogjakarta, 1999, hlm. 4 
kesamaan hak dalam pertukaran (prestasi - kontra prestasi) sebagaimana dipahami dalam konteks keadilan komutatif maupun konsep keadilan distributif sebagai landasan hubungan kontraktual.

\section{E. Metode Penelitian}

Metodologi merupakan salah satu cara yang dilakukan oleh peneliti untuk melakukan suatu penelitian. Salah satu tujuan dari dilakukanya suatu penelitian adalah untuk menemukan penemuanpenemuan baru serta informasiinformasi yang didapat melalui prosedur-prosedur penelitian yang ada, sehingga dapat dihasilkan suatu data penelitian yang falid dan dapat dipertanggung jawabkan baik dari segi ilmiah, maupun secara teoritis.

Secara teoritis, metode merupakan pedoman atau cara seorang ilmuan mempelajari dan memahami langkah-langkah yang dihadapi ${ }^{43}$ Jenis penelitian hukum dalam penulisan jurnal ini adalah normatif (doctrinal). Penelitian hukum doktrinal adalah penelitian-penelitian atas hukum yang dikonsepsikan dan dikembangkan atas dasar doktrin yang dianut sang pengkonsep dan /atau sang pengembangnya. ${ }^{44}$ Sedangkan pengertian lain mengenai penelitian normatif (doctrinal) adalah suatu prosedur penelitian ilmiah untuk menemukan kebenaran berdasarkan logika keilmuan hukum dari sisi normatif. ${ }^{45}$

Adapun pendekatan-pendekatan yang digunakan di dalam penelitian hukum adalah pendekatan undang-undang (statute approach), dan pendekatan

${ }^{43}$ Soejono Soekanto, Penelitian Hukum Normatif Suatu Tinjauan Singkat, Raja Grafindo Persada, Jakarta, 2007, hlm 6.

${ }^{44}$ Cholid Narbuko, Abu Achmadi, Metodologi Penelitian, Bumi Pustaka, Jakarta, 1997 hlm. 147.

${ }^{45}$ Johnny Ibrahim, Teori \& Metodologi Penelitian Hukum Normativ, Bayu Publishing, Malang, 2012 hlm. 57 
konseptual (conseptual approach). ${ }^{46}$ Spesifikasi penelitian yang digunakan yaitu berupaDeskriptif Analitis.

Dalam penelitian hukum ini, data yang diperoleh merupakan data secara kwalitatif, yaitu analisis yang bertujuan untuk memperoleh kedalaman data ${ }^{47}$, adapun data yang di dapatkan berupa data kalimat yang tersusun secara sistematis sehingga dapat dilakukan pembahasan dengan mudah. Menurut Soerjono Soekanto, ${ }^{48}$ pendekatan kwalitatif merupakan tata cara penelitian yang menghasilkan data secara deskriptif, yaitu apa yang dinyatakan oleh responden baik secara tertulis maupun secara lisan.

\section{F. Hasil Penelitian dan Pembahasan}

\section{Penerapan Asas Kebebasan Berkontrak Pada Perjanjian Baku Dalam}

\section{Mewujudkan Keadilan Para Pihak}

Asas kebebasan berkontrak terdapat di dalam Pasal 1338 ayat (1) KUHPerdata, bersama dengan asas konsensualisme dan asas kekuatan mengikat. Adapun bunyi pasal tersebut: "Semua persetujuan yang dibuat secara sah berlaku sebagai undang bagi mereka yang membuatnya." Pasal tersebut menegaskan bahwa: "Setiap perjanjian yang dibuat secara sah berlaku sebagai undang-undang bagi mereka yang membuatnya."Berdasarkan ketentuan di atas, tidak terdapat frasa yang menyebutkan "kebebasan berkontrak," sehingga tidak dapat dikatakan kalau

\footnotetext{
${ }^{46}$ Peter Mahmud Marzuki, Penelitian Hukum, Kencana, Jakarta: 2013 hlm. 133

${ }^{47}$ Bambang Suggono, Metode Penelitian Hukum PT Raja Grafindo Persada, Jakarta, 2007, hlm. 38

${ }^{48}$ Soerjono Soekanto, Pengantar Penelitian Hukum, UI-Press, Jakarta 1986,hlm 32.
} 
merupakan turunan dari asas kebebasan berkontrak. Hal ini tentunya tidak akan menimbulkan perdebatan, seandainya ketentuan tersebut semata-mata dimaknai sebagai pengkonkretan asas pacta sunt servanda, yaitu setiap perjanjian mengikat para pihak.

Dalam Pasal 1338 ayat (1) KUHPerdata sangat jelas dapat diperoleh arti yang demikian, bahwa perjanjian yang sah adalah sebagai undangundang bagi mereka yang membuatnya. Jika perjanjian disamakan dengan undang-undang, sudah pasti akan termaknai bahwa di dalam perjanjian itu, setiap pihak wajib menundukan dan mengikatkan diri dalam setiap pemenuhan hak dan kewajibannya masing-masing.

Andaikata Pasal 1338 ayat (1) KUHPerdata berbunyi "setiap perjanjian yang dibuat berlaku sebagai undang-undang bagi mereka yang membuatnya" maka tentunya dapat diperoleh pemaknaan bahwa yang namanya kontrak/perjanjian dapat dilaksanakan sebebas-bebasnya.

Pasal 1338 ayat (1) KUHPerdata bukanlah ketentuan yang dapat menjadi petunjuk kalau kontrak/perjanjian dapat dilaksanakan sebebasbebasnya. Akan tetapi pelaksanaan dari pada asas kebebasan berkontrak dibatasi oleh beberapa prasyarat. Dengan terdapatnya frasa “...dibuat secara sah..." dalam ketentuan tersebut, berarti menunjukkan kalau ada perjanjian yang dibuat secara sah, berarti sebaliknya ada juga perjanjian yang bisa 
dibuat tetapi tidak sah, dan kalau perjanjiannya tidak sah tidak dapat berlaku sebagai undang-undang bagi mereka yang membuatnya ${ }^{49}$.

Lanjut dari pada itu, penting untuk mengutip secara lengkap dari ketentuan Pasal 1338 KUHPerdata yang terdiri dari tiga ayat, yaitu:

(1). Setiap perjanjian yang dibuat secara sah berlaku sebagai undangundang bagi mereka yang membuatnya;

(2). Perjanjian-perjanjian itu tidak dapat ditarik kembali selain dengan sepakat kedua belah pihak, atau karena alasan-alasan yang oleh undangundang dinyatakan cukup untuk itu;

(3). Perjanjian-perjanjian harus dilaksanakan dengan itikad baik.

Berdasarkan ketentuan dari Pasal 1338 di atas yang terdiri atas 3 ayat, tidak ada frasa yang menyebutkan kontrak dapat dilaksanakan sebebasbebasnya. Setidak-tidaknya dari ayat (2) nya, justru mempertegas pelaksanaan kontrak mengalami pembatasan.

Ketentuan Pasal 1338 ayat (2) merupakan kalimat negatif, yang mana jika dipositifkan maka akan berbunyi: "Perjanjian-perjanjian itu dapat ditarik kembali selain dengan sepakat kedua belah pihak, atau karena alasan-alasan yang oleh undang-undang dinyatakan cukup untuk itu."

Jadi, kalau perjanjian tersebut bukan merupakan perjanjian yang sah, dapat ditarik kembali, meskipun tidak disepakati oleh kedua belah pihak. Atau karena alasan lainnya juga dapat ditarik kembali karena bertentangan dengan undang-undang. Sama halnya dengan ketentuan selanjutnya, yaitu Pasal 1338 ayat (3) yang menegaskan: "perjanjian-perjanjian harus dilaksanakan dengan itikad baik."

${ }^{49}$ Negara Hukum, Prinsip Kebebasan Berkontrak Terbatas, https://www. Negara hukum. com/ hukum/prinsip-kebebasan-berkontrak-terbatas.html, diakses pada tanggal $7 / 2 / 2020$ 
Pasal 1338 menunjukkan bahwa kebebasan berkontrak dibatasi oleh itikad baik masing-masing pihak. Jika dalam perjanjian itu terdapat salah satu pihak yang beritikad jahat, maka perjanjian tersebut dapat dibatalkan atau ditarik kembali.

Selain itu, masih banyak pembatasan mengenai asas kebebasan berkontrak. Jika Pasal 1338 ayat (1) menegaskan bahwa setiap perjanjian harus dibuat secara sah. Maka, kata "sah" di sini merujuk pada Pasal 1320 yang mengatur tentang syarat sahnya kontrak, yaitu kesepakatan, kecakapan, suatu hal tertentu, dan tidak boleh bertentang causa yang halal. Hal demikian menunjukkan kalau asas kebebasan berkontrak dibatasi oleh syarat-syarat sahnya suatu perjanjian.

Hal itu berlaku pula pada pembatasan-pembatasan yang lain, seperti: Pasal 1321 KUHPerdata, perjanjian karena kekhilafan, paksaan atau penipuan; Pasal 1335 KUHPerdata, perjanjian tanpa sebab, sebab yang palsu atau terlarang; Pasal 1337 KUHPerdata, sebab yang dilarang oleh undang-undang, bertentangan dengan ketertiban umum. Setiap ketentuan tersebut menjadi dasar sehingga suatu perjanjian dapat ditarik kembali, dapat dibatalkan atau batal demi hukum yang menunjukkan bahwa asas kebebasan berkontrak itu sifatnya terbatas.

Berdasarkan uraian di atas, maka asas hukum yang dapat dikatakan memiliki kedudukan paling utama dalam hukum perikatan, yaitu asas itikad baik. Suatu perjanjian dapat dikatakan tidak sah, tidak memenuhi syarat sahnya perjanjian jika menyimpangi itikad baik dari salah satu pihak. Suatu 
perjanjian kalau terjadi paksaan, kekhilafan, penipuan merupakan penyimpangan terhadap asas itikad baik. Suatu perjanjian bertentangan dengan undang-undang, ketertiban dan kesusilaan juga bertentangan dengan itikad baik. Terdapat keadaan-keadaan lain atau prasyarat yang menyebabkan kontrak tidak dapat dilaksanakan sebebas-bebasnya, misalnya karena terjadi kecacatan kehendak, bertentangan dengan undang-undang, ketertiban, dan kesusilaan, yang demikian itu juga merupakan bentuk konkret mengenai tidak terpenuhinya asas itikad baik dalam pelaksanaan suatu perjanjian.

Para ahli hukum, rata-rata mengemukakan bahwa kebebasan berkontrak memberikan jaminan kebebasan kepada seseorang untuk secara bebas dalam beberapa hal yang berkaitan dengan perjanjian, diantaranya: ${ }^{50}$

a. Bebas menentukan apakah ia akan melakukan perjanjian atau tidak;

b. Bebas menentukan dengan siapa ia akan melakukan perjanjian;

c. Bebas menentukan isi atau klausul perjanjian;

d. Bebas menentukan bentuk perjanjian;

e. Kebebasan-kebebasan lainnya yang tidak bertentangan dengan peraturan perundang-undangan

Perihal jaminan kebebasan yang tidak dapat dibatasi dari apa yang telah disebutkan di atas, hanya dapat terjadi pada keadaan yang pertama, yaitu bebas menentukan apakah ia akan melakukan perjanjian atau tidak. Hal ini terkait dengan persoalan kehendak, atau kemauan dari seseorang

50 Ahmadi Miru, Hukum Kontrak, Perancangan Kontrak, Rajawali Pers, Jakarta, 2007, hlm. 4 
yang tidak dapat diganggu gugat, karena belum terjadi hubungan dua pihak, sebagaimana hukum hanya dapat mengatur tata pergaulan sosial.

Sementara pada jenis-jenis kebebasan lainnya, masih ada pembatasannya. Bebas menentukan dengan siapa ia akan melakukan perjanjian, dapat dibatasi oleh pihak yang dianggap tidak cakap melakukan tindakan hukum. Bebas menentukan isi atau klausul perjanjian, dapat dibatasi oleh klausul yang tidak boleh bertentangan dengan undang-undang, ketertiban dan kesusilaan. Bebas menentukan bentuk perjanjian, dapat dibatasi oleh perjanjian yang tidak boleh bertentangan dengan causa yang halal. Untuk kebebasan-kebebasan lainnya yang tidak bertentangan dengan undang-undang, tidak perlu dipersoalkan lagi pembatasannya, sebab kalau sudah dikatakan tidak boleh bertentangan dengan undang-undang, itu sudah pasti wujud kebebasannya sudah dibatasi. Namun dalam praktiknya, asas kebebasan berkontrak ini umumnya dipergunakan sebagai dasar dalam pemanfaatan perjanjian baku yang mengatur transaksi konsumen dengan pelaku usaha. Dengan alasan kepraktisan dan mampu menghemat biaya serta waktu, kontrak baku baku ini dipergunakan secara luas pada hampir semua kegiatan bisnis diantaranya kontrak (polis) asuransi, kontrak di bidang perbankan, kontrak sewa guna usaha, kontrak jual beli rumah/apartemen dari perusahaan (real estate), kontrak sewa menyewa 
gedung perkantoran, kontrak pembuatan kartu kredit, kontrak pengiriman barang (darat, laut dan udara, dan sebagainya ${ }^{51}$.

Apabila mengacu pada ketentuan Pasal 1320 KUHPerdata tersebut, dapat diasumsikan adanya penyimpangan penerapan asas kebebasan berkontrak dalam perjanjian baku pada kegiatan bisnis, karena kesepakatan bisnis yang terjadi bukan karena proses negosiasi yang seimbang di antara para pihak, tetapi perjanjian itu terjadi dengan cara pihak yang satu telah menyiapkan syarat-syarat baku (klausula baku) pada suatu formulir perjanjian yang sudah dicetak dan disodorkan kepada pihak lain untuk disetujui dengan hampir tidak memberikan kebebasan sama sekali kepada pihak yang lain untuk melakukan negosiasi atas syarat-syarat yang disodorkan. ${ }^{52}$

Pihak yang lemah (biasanya dalam hal ini konsumen) hanya diperkenankan untuk membaca syarat-syarat yang diajukan pihak yang kedudukannya kuat, dan apabila ia menyetujui persyaratan tersebut maka konsumen dipersilahkan untuk menandatanganinya (take it), namun sebaliknya apabila konsumen tidak menyetujui persyaratan yang diajukan pelaku usaha, maka transaksi tidak dapat dilanjutkan (leave it). Itulah

\footnotetext{
${ }^{51}$ Munir Fuady, Hukum Kontrak (Dari Sudut Pandang Hukum Bisnis), Buku Kedua Citra Aditya Bakti, Bandung,2003, hlm. 77

${ }^{52}$ Dedi Harianto, Asas Kebebasan Berkontrak: Problematika Penerapannya Dalam Kontrak Baku Antara Konsumen Dengan Pelaku Usaha, Jurnal Hukum Samudra keadilan, Volume 11, Nomor 2, Juli-Desember 2016, hlm 151
} 
sebabnya perjanjian baku ini kemudian dikenal dengan penyebutan "take it or leave it contract." 53

Adanya unsur pilihan ini oleh sementara pihak dikatakan, perjanjian baku tidaklah melanggar asas kebebasan berkontrak (Pasal 1320 Jo. Pasal 1338 KUHPerdata) dengan masih diberikannya hak kepada konsumen untuk menyetujui (take it) atau menolak perjanjian yang diajukan kepadanya (leave it). ${ }^{54}$

Apabila dalam suatu perjanjian, kedudukan para pihak tidak seimbang, maka pihak yang lemah biasanya tidak dalam keadaan yang betul-betul bebas untuk menentukan apa yang diinginkan dalam perjanjian. Dalam hal yang demikian pihak yang memiliki posisi lebih kuat biasanya mempergunakan kesempatan tersebut untuk menentukan klausula-klausula tertentu dalam kontrak baku, sehingga isi perjanjian hanya mengakomodir kepentingan pihak yang kedudukannya lebih kuat. ${ }^{55}$ Sehingga dapat dipastikan bahwa perjanjian tersebut memuat klausul-klausul yang menguntungkan baginya atau meringankan atau menghapus beban-beban atau kewajiban tertentu yang seharusnya menjadi bebannya, yang biasa dikenal dengan "klausula eksonerasi". Oleh karena itu, apabila terdapat posisi yang tidak seimbang di antara para pihak, maka hal ini harus ditolak karena akan berpengaruh terhadap substansi maupun maksud dan tujuan

\footnotetext{
${ }^{53}$ Shidarta, Hukum Perlindungan Konsumen Indonesia, Grasindo, Jakarta , 2000, hlm.
} 120.

${ }_{55}^{54}$ Ibid

${ }^{55}$ Ahmadi Miru \& Sutarman Yodo, Hukum Perlindungan Konsumen, Raja Grafindo Persada, Jakarta,2004, hlm.114 
dibuatnya kontrak tersebut. Interpretasi terhadap istilah keseimbangan terhadap kandungan substansi aturan tersebut adalah :

a. Lebih mengarah kepada keseimbangan posisi para pihak artinya dalam hubungan kontraktual tersebut posisi para pihak diberi muatan keseimbangan;

b. Kesamaan pembagian hak dan kewajiban dalam hubungan kontraktual, seolah-olah tanpa memperhatikan proses yang berlangsung dalam penentuan hasil pembagian tersebut;

c. Keseimbangan seolah sekedar merupakan hasil akhir sebuah proses;

d. Intervensi Negara merupakan instrument pemaksa dan mengikat agar terwujud keseimbangan posisi para pihak;

e. Pada dasarnya keseimbangan posisi para pihak hanya dapat dicapai pada syarat dan kondisi yang sama (ceteris paribus). ${ }^{56}$

Penerapan klausul-klausul tertentu yang dilakukan oleh pihak yang memiliki kedudukan lebih kuat yang mengakibatkan kerugian bagi pihak yang lemah, biasanya dikenal dengan "penyalahgunaan keadaan." ${ }^{, 57}$ Penyalahgunaan keadaan terjadi apabila orang mengetahui atau seharusnya mengerti bahwa pihak lain karena suatu keadaan khusus seperti keadaan darurat, ketergantungan, tidak dapat berpikir panjang, keadaan jiwa yang abnormal atau tidak berpengalaman tergerak melakukan suatu perbuatan hukum, meskipun ia

\footnotetext{
${ }^{56}$ Agus Yudha, Hukum Perjanjian, Asas Proporsionalitas Dalam Kontrak Komersial, Kencana Prenada Media Group, Jakarta,2010, hlm. 84

57 Ahmadi Miru, Hukum Kontrak Perancangan Kontrak, RajaGrafindo Persada, Jakarta,2008, hlm. 41.
} 
tahu atau seharusnya mengerti bahwa sebenarnya ia harus mencegahnya. ${ }^{58}$ Misalnya nasabah debitur pada lembaga perbankan tidak memiliki kehendak bebas dalam menerima atau menolak formulir perjanjian kredit yang diajukan bank, karena terdesak kebutuhan dana yang harus segera dipenuhinya terpaksa menyetujui syarat-syarat yang ditentukan secara sepihak oleh bank, walaupun syarat-syarat tersebut berpotensi merugikan nasabah debitur.

Berkenaaan dengan hal tersebut, pakar hukum Indonesia, Mariam Darus Badrul Zaman menyimpulkan : "perjanjian baku itu bertentangan dengan asas kebebasan berkontrak yang bertanggung jawab, terlebih lebih lagi ditinjau dari asas-asas hukum nasional dan asas keadilan dimana pada akhirnya kepentingaan masyarakatlah yang didahulukan. Dalam perjanjian baku, kedudukan pelaku usaha dengan konsumen tidak seimbang. Posisi yang didominasi oleh pelaku usaha, membuka peluang luas bagi dirinya untuk menyalahgunakan kedudukannya. Pelaku usaha hanya mengatur hak-haknya dan tidak kewajibannya. Jika dikaitkan dengan teori keadilan maka keadilan dalam berkontrak lebih terwujud apabila pertukaran kepentingan para pihak terdistribusi sesuai dengan hak dan kewajibannya secara proporsional. Oleh karena itu jika perjanjian baku tidak mencerminkan keseimbangan antara hak dan kewajiban kedua belah pihak maka perjanjian baku ini tidak boleh dibiarkan tumbuh secara liar karena tidak mewujudkan keadilan para pihak dan perlu ditertibkan. ${ }^{59}$

58 Purwahid Patrik, Dasar-dasar Hukum Perikatan, Mandar Maju, Bandung, 1994, hlm. 61.

${ }^{59}$ Mariam Darus Badrulzaman, Op.Cit., hlm. 54 


\section{Kedudukan Perjanjian Baku Agar Dapat Mencapai Keadilan Bagi}

\section{Kedua Belah Pihak}

Kontrak sebagai wadah yang mempertemukan kepentingan satu pihak dengan pihak lain, guna membentuk pertukaran kepentingan yang adil bagi kedua belah pihak, namun pada perjanjian baku kedudukan para pihak tidaklah seimbang, karena pelaku usaha sebagai pihak yang ekonominya kuat sedangkan konsumen berada pada pihak yang ekonominya lemah. Pelaku usaha sebagai pihak yang ekonominya kuat merekalah yang membuat atauran-aturan yang terdapat dalam perjanjian baku, dimana aturan tersebut kadangkala bersifat berat sebelah.

Sluitjer mengatakan bahwa perjanjian baku bukanlah perjanjian, karena kedudukan pengusaha didalam perjanjian tersebut adalah seperti pembentuk undang-undang swasta (legio particuliere wet-gever). Syaratsyarat yang ditentukan oleh pengusaha/pelaku usaha dalam suatu perjanjian tersebut adalah peraturan-peraturan dan bukanlah perjanjian. Hal demikian juga dikemukan oleh Mariam Darus Badrulzaman bahwa kedudukan pengusaha dan konsumen tidak seimbang dalam perjanjian baku, perjanjian baku dinilai cenderung berat sebelah. Dalam hal ini, konsumen tidak diberikan keleluasan dalam menentukan isi perjanjian karena konsumen tidak mempunyai kewenangan. Sehingga perjanjian baku dinilai tidak 
memenuhi aturan yang dikehendaki oleh Pasal 1320 KUH Perdata jo. Pasal 1338 KUH Perdata. ${ }^{60}$

Bertitik tolak dari paparan di atas, asas kebebasan berkontrak terhadap perjanjian baku harus dibatasi bekerjanya agar kontrak yang dibuat berlandaskan asas itu tidak sampai menjadi perjanjian yang berat sebelah atau timpang. Ada beberapa pembatasan yang diberikan oleh pasal-pasal KUHPerdata terhadap asas ini, yang membuat asas ini merupakan asas yang tidak terbatas, antara lain Pasal 1320 ayat (1); ayat (2); dan ayat (4), Pasal 1332, Pasal 1337 dan Pasal 1338 ayat (3). Pasal 1320 ayat (1) tersebut memberikan petunjuk bahwa hukum perjanjian dikuasai oleh "asas konsensualisme" dan dibatasi oleh asas ini.

Pasal ini juga mengandung pengertian bahwa kebebasan suatu pihak untuk menentukan isi kontrak dibatasi oleh sepakat pihak lainnya. Dari Pasal 1320 ayat (2) KUHPerdata dapat disimpulkan bahwa kebebasan orang untuk membuat perjanjian dibatasi oleh kecakapannya untuk membuat kontrak. Bagi seseorang yang menurut ketentuan undang-undang tidak cakap untuk membuat kontrak, sama sekali tidak mempunyai kebebasan membuat kontrak. Pasal 1320 ayat (4) KUHPerdata jo 1337 KUHPerdata menentukan bahwa para pihak tidak bebas untuk membuat kontrak yang menyangkut causa yang dilarang oleh undang-undang atau bertentangan dengan kesusilaan atau ketertiban umum adalah tidak sah.

\footnotetext{
${ }^{60}$ Mariam Darus Badrulzaman, Aneka Hukum Bisnis, ..Op.Cit, hlm. 105
} 
Menurut Pasal 1332 KUHPerdata hanya barang yang dapat diperdagangkan saja yang dapat dapat menjadi pokok persetujuan. Artinya hanya barang yang mempunyai nilai ekonomis yang bisa dijadikan objek dari perjanjian. Pasal 1338 ayat (3) KUHPerdata menentukan tentang berlakunya "asas itikad baik" dalam melaksanakan kontrak. Artinya jika kontrak yang dibuat dengan berlandaskan itikad buruk, misalnya atas dasar penipuan, maka perjanjian itu tidak sah. Dengan demikian, asas itikad baik mengandung pengertian bahwa kebebasan suatu pihak membuat perjanjian tidak dapat diwujudkan sekehendaknya, tetapi dibatasi oleh itikad baiknya. Sekalipun asas kebebasan berkontrak yang diakui oleh KUHPerdata pada hakikatnya juga dibatasi oleh KUHPerdata itu sendiri, tetapi daya kerjanya masih sangat longgar. Kelonggaran ini telah menimbulkan ketimpanganketimpangan dan ketidakadilan bagi para pihak.

Menurut Syaifuddin ${ }^{61}$ secara konkrit, kontrak baku yang berkembang dalam praktik hukum kontrak mempunyai ciri-ciri sebagai berikut :

a. Proses pembuatannya secara sepihak oleh pihak yang mempunyai kedudukan atau posisi tawar menawar yang lebih kuat daripada pihak lainnya;

b. Pihak yang kedudukan atau posisi tawar-menawarnya lebih lemah, tidak dilibatkan sama sekali dalam menentukan substansi kontrak;

${ }^{61}$ Syaifuddin, Muhammad, Hukum Kontrak dalam Perspektif Filsafat, Teori, Dogmatik, dan Praktik Hukum (Seri Pengayaan Hukum Perikatan). Cetakan I. CV. Mandar Maju, Bandung, 2012. hlm 219 
c. Pihak yang kedudukan atau posisi tawar menawarnya lebih lemah, meyepakati atau menyetujui substansi kontrak secara terpaksa, karena didorong oleh kebutuhan;

d. Kontrak dibuat dalam bentuk tertulis, formatnya tertentu dan massal (jumlahnya banyak).

Kedudukan Perjanjian baku dibuat oleh pihak yang ekonominya kuat terhadap debitur yang kedudukan ekonominya lemah. Misalnya dalam perjanjian baku dalam bidang Asuransi, para pihaknya adalah penanggung dan tertanggung. Pihak penanggung merupakan pihak yang telah menyiapkan substansi perjanjian baku tersebut. Sementara itu, pihak tertanggung tinggal menandatangani perjanjian tersebut. Jadi pihak yang sangat berperan dalam menentukan perjanjian baku adalah pihak yang ekonomi kuat dan pihak inilah yang menyusun klausul-klausulnya.

Penggunaan kontrak baku dalam dunia bisnis dewasa ini menimbulkan permasalahan hukum yang memerlukan pemecahan. Secara tradisional suatu perjanjian terjadi didasarkan pada asas kebebasan berkontrak di antara dua pihak yang memiliki kedudukan yang seimbang. Kesepakatan yang didapat dalam perjanjian itu merupakan hasil negosiasi di antara para pihak. ${ }^{62}$ Proses semacam itu tidak ditemukan dalam perjanjian baku. Hampir tidak ada kebebasan dalam menentukan isi perjanjian dalam proses negosiasi. Isi atau syarat-syarat perjanjian telah ditentukan secara sepihak oleh pengusaha.

${ }^{62}$ R.M Panggabean, Keabsahan Perjanjian dengan Klausul Baku. Jurnal Hukum Ius Quia Iustum.Jakarta, 2010. hlm. 652 
Perjanjian baku tidak mencerminkan asas keseimbangan para pihak dalam kontrak. Ketidakseimbangan kedudukan dalam perjanjian baku diakibatkan karena para pihak memiliki bargaining position yang tidak sama sehingga menimbulkan “unreal bargaining”. Ketidakseimbangan kedudukan dalam perjanjian baku disebabkan oleh beberapa hal ${ }^{63}$ :

a. Pembuat kontrak baku pada umumnya memiliki penguasaan terhadap sumber daya (ekonomi, teknologi, atau ilmu) yang lebih tinggi dibandingkan pihak penerima kontrak baku. Salah satu bentuknya adalah terlihat dalam klausul-klausul yang terdapat dalam bentuk standar atau baku yang isinya cenderung berat sebelah atau disebut sebagai klausula eksemsi atau eksonerasi. Klausula ini memberikan batasan dan atau pengalihan bentuk tanggung jawab terhadap suatu resiko bisnis kepada pihak lainnya sehingga dapat menimbulkan kerugian atau keuntungan yang tidak wajar terhadap salah satu pihak. Ketidakseimbangan kedudukan ini dapat dilihat dengan adanya klausula-klausula di dalam kontrak baku yang semata-mata hanya mementingkan kepentingan si pelaku usaha atau pemilik modal yang posisi tawarnya lebih kuat.

b. Keterbatasan akses informasi yang seharusnya diperoleh oleh penerima kontrak baku. Penerima kontrak dalam menandatangani kontrak baku hanya berfokus pada hal-hal penting dalam kontrak, hal-hal seperti pemilihan forum penyelesaian sengketa, ganti rugi apabila wanprestasi, kebijakan-

${ }^{63}$ Aryo Dwi Prasnowo, Siti Malikhatun Badriyah, Implementasi Asas Keseimbangan Bagi Para Pihak dalam Perjanjian Baku, Jurnal Magister Hukum Udayana (Udayana Master Law Journal), Vol. 8 No. 1 Mei 2019, Denpasar, 2019, hlm 61 
kebijakan yang berubah, dan sebagainya, tidak menjadi perhatian Keterbatasan dalam hak untuk menyampaikan pendapat dalam kontrak terhambat karena pihak penerima kontrak dihadapkan pada pilihan "take it or leave it" terutama apabila penerima kontrak dihadapkan pada obyek kontrak yang bersifat pemenuhan kebutuhan mendasar seperti kebutuhan akan sandang, pangan dan papan, maka pilihan ini akan menimbulkan dilema.

c. Adanya kelemahan di bidang ekonomi atau kelemahan di bidang pengetahuan pada pihak penerima kontrak baku menyebabkan aspek keseimbangan kedudukan menjadi tidak terpenuhi. Pihak penerima kontrak baku pada umumnya menandatangani kontrak yang disodorkan akibat kebutuhan terhadap obyek kontrak.

d. Adanya kekuasaan atau kewenangan yang dimiliki salah satu pihak lebih besar, hal ini tampak dalam kontrak yang dilakukan antara pemerintah dalam kapasitasnya selaku subyek hukum privat dalam hubungan keperdataan misalnya kontrak pengadaan barang dan jasa.

Perjanjian baku yang ditetapkan secara sepihak tidak menutup kemungkinan dapat disalahgunakan oleh salah satu pihak yang memiliki posisi tawar lebih tinggi untuk menekan pihak yang lemah kedudukannya. Sementara pihak yang lemah kedudukannya ini hanya bisa menerima saja apa yang disodorkan, sehingga seringkali menanggung kerugian. Tetapi mengapa hal ini masih saja terjadi? Hal ini didasari oleh adanya pertimbangan ekonomis, yaitu untuk mengurangi biaya, tenaga, dan waktu yang timbul dalam pembuatan 
sebuah perjanjian serta praktis karena dapat digunakan dan ditandatangani sewaktu-waktu.

Hubungan antara para pihak yang tidak seimbang dalam sebuah perjanjian tentu menjadi tidak adil bagi para pihak. Ketidakadilan yang terjadi pada suatu hubungan para pihak yang tidak seimbang dinamakan undue influence, sedangkan ketidakadilan terjadi pada suatu keadaan (bukan hubungan) yang tidak seimbang dinamakan unconscionability. ${ }^{64}$ Hakikat dari keadilan adalah terpenuhinya segala sesuatu yang menjadi hak dan kewajibannya. Keadilan menuntut adanya tindakan yang proporsional, sesuai, seimbang, selaras dengan setiap hak setiap orang.

Kedudukan atau posisi tawar yang tidak seimbang dalam sebuah perjanjian, merupakan hal yang bertentangan dengan tujuan hukum yaitu keadilan. Jika dihubungkan dengan teori keadilan maka perjanjian dibentuk sebagai wadah yang mempertemukan kepentingan para pihak sebagai pertukaran kepentingan yang adil. ${ }^{65}$

Memperhatikan problematika yang timbul akibat penerapan asas kebebasan berkontak dalam perjanjian baku yang tidak disertai dengan adanya keseimbangan kedudukan pelaku usaha dengan konsumen, sehingga terjadi ekploitasi pihak yang kuat (pelaku usaha) terhadap pihak yang lemah (konsumen), maka negara berkewajiban melakukan pembatasan terhadap penerapan asas kebebasan berkontrak.

${ }^{64}$ Hardijan Rusli. Hukum Perjanjian Indonesia dan Common Law. Pustaka Sinar Harapan, Jakarta,1996. hlm. 113

${ }^{65}$ Teguh Wicaksono Saputro. Penerapan Asas Keseimbangan dan Asas Kebebasan Berkontrak dalam Putusan Pengadilan, Tesis, Program Pascasarjana Magister Hukum Universitas Indonesia, 2011. hlm 35 
Walaupun perjanjian antara satu pihak dengan pihak yang lain tersebut bersifat privat atau perdata, artinya hanya mengikat kedua belah pihak. Karena itu pihak lain tidak mempunyai hak untuk ikut campur dalam perjanjian tersebut, tidak juga Negara (dalam bentuk undang-undang). Negara hanya bisa melakukan intervensi dalam hubungan perdata apabila salah satu pihak yang melakukan hubungan perdata dalam posisi yang lemah. Negara mempunyai tugas untuk melindungi pihak yang lemah tersebut agar mempunyai posisi yang kuat, misalnya perjanjian harus memenuhi syarat sahnya perjanjian, materi perjanjian tidak boleh bertentangan dengan peraturan perundangundangan, ketertiban umum dan kesusilaan, dan perjanjian tidak boleh timbul akibat adanya paksaan, kekhilafan, ataupun penipuan. ${ }^{66}$

Berkaitan dengan hal itu, Agus Yudha Hernoko mengemukakan bahwa seringkali terjadi kesalahan persepsi mengenai eksistensi kontrak yang pada akhirnya menjebak dan menyesatkan penilaian objektif, khususnya mengenai pertanyaan "apakah suatu perjanjian itu seimbang atau tidak seimbang". Lebih lanjut dikatakan oleh Agus Yudha Hernoko, bahwa kesesatan tersebut terjadi karena hanya bergelut pada perbedaan status masing-masing pihak yang berkontrak. Pandangan tersebut tidak sepenuhnya salah, namun akan menjadi lebih fair dan objektif apabila menilai keberadaan suatu perjanjian terutama dengan mencermati substansinya, serta kategori kontrak yang bersangkutan. ${ }^{67}$

\footnotetext{
${ }^{66}$ Gemala Dewi, Aspek-aspek Hukum Dalam Perbankan dan Perasuransian Syariah, Kencana, Jakarta . 2004 hlm 187

67 Agus Yudha Hernoko, Hukum Perjanjian Asas Proporsionalitas dalam Kontrak Komersial. Kencana Prenada Media Grup, Jakarta,2010. hlm. 4-5
} 
Interpretasi perjanjian dalam hubungannya dengan keseimbangan perjanjian, memperlihatkan bahwa keseimbangan suatu perjanjian tidak semata-mata mutlak ditentukan oleh kedudukan para pihak saja, tetapi juga ditentukan oleh aspek itikad baik. Karena adanya ketidakseimbangan kedudukan antara para pihak, maka perlu adanya campur tangan negara untuk turut serta mengembalikan keseimbangan kedudukan para pihak. Sehingga dapat merepresentasikan kepentingan para pihak secara adil. Perlunya campur tangan negara tersebut didasarkan pada teori H.L.Hart dalam "the minimum contect of natural law (teori perlindungan minimum)" bahwa sifat manusia yang rentan (vulnerable) merupakan salah satu alasan perlunya hukum. ${ }^{68}$ Dalam kaitan terhadap pembuatan perjanjian baku, diperlukan campur tangan negara dalam bentuk pembuatan aturan hukum maupun penanganan perkara-perkara perjanjian baku melalui pengadilan (putusan-putusan pengadilan) untuk melindungi pihak yang lemah, pihak yang memiliki bargaining power lebih rendah akibat keterbatasan terhadap akses dan informasi, pendidikan dan modal.

Berdasarkan teori keseimbangan, tidak terpenuhinya unsur keseimbangan berpengaruh terhadap kekuatan hukum dalam sebuah perjanjian. Keseimbangan akan tercapai manakala para pihak bersepakat untuk bersamasama saling mengikatkan diri tanpa adanya tekanan dari pihak manapun. Para pihak yang berada dalam posisi yang setara dan memiliki hak serta kewajiban yang sama. Apabila sudah setara, maka para pihak dapat melakukan kegiatan

${ }^{68}$ H.L.A.Hart. The Concept of Law. Oxford: Clarendon Press. 1981 hlm. 189-195 
bisnisnya dengan lebih baik, sehingga keadilan dan kesejahteraan rakyat dapat tercapai dan dengan adanya intervensi dari negara atau pemerintah, diharapkan dapat ditegakkan keseimbangan dalam perjanjian tersebut.

\section{G. Kesimpulan}

1. Penerapan asas kebebasan berkontrak pada perjanjian baku tidak bisa dibendung dan dihalangi, karena dia tumbuh dan berkembang sejalan dengan pertumbuhan dan perkembangan dunia bisnis yang didasari pada adanya suatu kebutuhan masyarakat akan perjanjian baku tersebut, namun keadilan dalam berkontrak lebih terwujud apabila adanya pertukaran kepentingan para pihak terdistribusi sesuai dengan hak dan kewajibannya secara proporsional. Oleh karena itu jika perjanjian baku tidak mencerminkan keadilan antara hak dan kewajiban kedua belah pihak maka perjanjian baku ini tidak boleh dibiarkan tumbuh secara liar karena tidak mewujudkan keadilan para pihak dan hal yang bertentangan dengan salah satu tujuan hukum yaitu keadilan

2. Memperhatikan problematika yang timbul akibat penerapan asas kebebasan berkontak dalam perjanjian baku yang tidak disertai dengan adanya keseimbangan kedudukan pelaku usaha dengan konsumen, akan menimbulkan ekploitasi pihak yang kuat (pelaku usaha) terhadap pihak yang lemah (konsumen), maka negara berkewajiban melakukan pembatasan terhadap penerapan asas kebebasan berkontrak. 


\section{H. Saran}

1. Pemerintah dan badan legeslatif segera untuk membuat Undang-Undang Perjanjian standar/baku secara khusus, karena ketentuan perjanjian yang kita pakai selama ini yaitu ketentuan KUHPerdata peninggalan zaman Hindia Belanda yang sudah tidak sesuai lagi dengan perkembangan zaman .

2. Kepada para pihak (kreditur dan debitur), dalam suatu perjanjian baku sebaiknya hanya ditulis hal-hal secara garis besarnya saja, bukan pada klausula-klausula yang ada di dalamnya secara mendetail bahkan adanya klausula eksonerasi yang memberatkan salah satu pihak, hal ini bertujuan untuk memberikan ruang bagi para pihak untuk melakukan negosiasi klausula-klausula yang ada di dalam perjanjian itu. 


\section{DAFTAR PUSTAKA}

\section{A. Buku :}

Abdulkadir Muhamad, Hukum Perikatan, Citra Aditya Bandung, 1992.

Agus Yudha Hernoko, Hukum Perjanjian Asas Proporsionalitas dalam Kontrak Komersial. Kencana Prenada Media Grup, Jakarta,2010.

Agus Yudha Hernoko, Keseimbangan Versus Keadilan Dalam Kontrak (Upaya Menata Struktur Hubungan Bisnis dalam Perspektif Kontrak yang Berkeadilan), Airlangga University Press,2010.

Agus Yudha, Hukum Perjanjian, Asas Proporsionalitas Dalam Kontrak Komersial, Kencana Prenada Media Group, Jakarta,2010.

Ahmadi Miru \& Sutarman Yodo, Hukum Perlindungan Konsumen, Raja Grafindo Persada, Jakarta,2004.

Ahmadi Miru, Hukum Kontrak Perancangan Kontrak, RajaGrafindo Persada, Jakarta,2008.

Ahmadi Miru, Hukum Kontrak, Perancangan Kontrak, Rajawali Pers, Jakarta, 2007.

Andre Ata Ujan, Keadilan dan Demokrasi (Telaah Filsafat Politik John Rawls), Kanisius, Yogjakarta, 1999.

Andre Ata Ujan, Keadilan dan Demokrasi (Telaah Filsafat Politik John Rawls) Keadilan dan Demokrasi (Telaah Filsafat Politik John Rawls), Kanisius, Yogjakarta, 1999.

Bambang Suggono, Metode Penelitian Hukum PT Raja Grafindo Persada, Jakarta, 2007.

Burhanuddin Salam, Etika Sosial, Rineka Cipta, Jakarta, 1997.. 
Cholid Narbuko, Abu Achmadi, Metodologi Penelitian, Bumi Pustaka, Jakarta, 1997 .

E. Sumaryono, Etika Hukum Relevansi Teori Hukum Kodrat Thomas Aquinas, Kanisius, Yogyakarta, 2002.

Gemala Dewi, Aspek-aspek Hukum Dalam Perbankan dan Perasuransian Syariah, Kencana, Jakarta,2004 .

H.L.A.Hart. The Concept of Law. Oxford,Clarendon Press. 1981 .

Hardijan Rusli. Hukum Perjanjian Indonesia dan Common Law. Pustaka Sinar Harapan, Jakarta,1996.

Ismail Sunny, dan Muhammad Rasyid, Negara Hukum (Suatu Study Tentang Suatu Prinsip-prinsipnya Dilihat Dari Segi Hukum Islam, Implementasinya Pada Periode Negara Madinah Dan Masa Kini), Kencana Prenada Media Group, Jakarta,2010.

Johnny Ibrahim, Teori \& Metodologi Penelitian Hukum Normativ, Bayu Publishing, Malang, 2012 .

K. Bertens, Pengantar Etika Bisnis, Kanisius, Yogjakarta, 2000.

Koentjaraningrat, Metode-metode Penelitian Masyarakat, Edisi Ketiga, Gramedia, Jakarta, 1993,

Mardalis, Metode Penelitian (Suatu Pendekatan Proposal), Bumi Aksara. Jakarta, 1999.

Mariam Darus Badrulzaman, Aneka Hukum Bisnis, Alumni, Bandung, 1994.

Munir Fuady, Hukum Kontrak (Dari Sudut Pandang Hukum Bisnis), Buku Kedua Citra Aditya Bakti, Bandung, 2003.

O. Notohamidjojo, Masalah: Keadilan, Tirta Amerta, Semarang, 1971.

Paul Edward, disitir oleh juhaya S. Praja, Teori Hukum Dan Aplikasinya. Pustaka Setia, Bandung, 2011.

Peter Mahmud Marzuki, "Batas-Batas Kebebasan Berkontrak", Artikel, Majalah Yuridika Volume 18 No.3, Bandung, 2003

, Penelitian Hukum, Kencana, Jakarta: 2013.

Purwahid Patrik, Dasar-dasar Hukum Perikatan, Mandar Maju, Bandung, 1994.

R. Subekti, Aspek-Aspek Hukum Perikatan Nasional, Alumni, Bandung,1986. 
R.M Panggabean, Keabsahan Perjanjian dengan Klausul Baku. Jurnal Hukum Ius Quia Iustum.Jakarta, 2010.

R.Setiawan, Pokok-Pokok Hukum Perikatan, Bina Cipta, Bandung, 1979,

Ridwan Khairandy, Itikad Baik dalam Kebebasan Berkontrak, Universitas Indonesia, Fakultas Hukum, Pascasarjana, 2003.

Shidarta, Hukum Perlindungan Konsumen Indonesia, Grasindo, Jakarta , 2000.

Soejono Soekanto, Penelitian Hukum Normatif Suatu Tinjauan Singkat, Raja Grafindo Persada, Jakarta, 2007.

Soerjono Soekanto, Pengantar Penelitian Hukum, UI-Press, Jakarta 1986.

Subekti, Hukum Perjanjian, Intermassa, Jakarta. 1987,

Syaifuddin, Muhammad, Hukum Kontrak dalam Perspektif Filsafat, Teori, Dogmatik, dan Praktik Hukum (Seri Pengayaan Hukum Perikatan). Cetakan I. CV. Mandar Maju, Bandung, 2012.

Tim Lindsey, et.al. Hak Kekayaan Intelektual Suatu Pengantar, Asian Law Group bekerjasama dengan PT Alumni, Bandung, 2003.

Uber Silalahi, Metode dan Metodologi Penelitian. Bina Budaya, Bandung 1998.

Wacks, Raymond, Jurisprudence, Blackstone Press Limited, London, 1995.

Yohanes Sogar Simamora, Hukum Perjanjian, LaksBang PRESSindo, Yogyakarta, 2009.

\section{B. Peraturan Perundang-undangan}

Undang-Undang Dasar Negara Republik Indonesia Tahun 1945.

Kitab Undang-Undang Hukum Perdata

Undang-Undang Republik Indonesia Nomor 8 Tahun 1999, Tentang UndangUndang Perlindungan Konsumen

\section{Sumber Lain:}

\section{Jurnal dan Makalah}

Aryo Dwi Prasnowo, Siti Malikhatun Badriyah, Implementasi Asas Keseimbangan Bagi Para Pihak dalam Perjanjian Baku, Jurnal 
Magister Hukum Udayana (Udayana Master Law Journal), Vol. 8 No. 1

Mei 2019, Denpasar, 2019

Dedi Harianto, Asas Kebebasan Berkontrak: Problematika Penerapannya Dalam Kontrak Baku Antara Konsumen Dengan Pelaku Usaha, Jurnal Hukum Samudra keadilan, Volume 11, Nomor 2, Juli-Desember 2016.

Lina Jamilah, Asas Kebebasan Berkontrak Dalam Perjanjian Standar Baku, Jurnal Ilmu Hukum, Syiar Hukum, Fh.Unisba. Vol. Xiii. No. 1 Bandung, 2012.

M Faiz mufidi, Perjanjian Alih Teknologi Dalam Bisnis Frenchise sebagai Sarana Pengenbangan Hukum Ekonomi, Disertasi Doktor, Universitas Padjajaran, Bandung, 2008.

Muhamad Hasan Muaziz dan Achmad Busro, Pengaturan Klausula Baku Dalam Hukum Perjanjian Untuk Mencapai Keadilan Berkontrak, Jurnal Law Reform Program Studi Magister Ilmu Hukum, Fakultas Hukum Universitas Diponegoro, Volume 11, Nomor 1, Semarang, 2015 .

Teguh Wicaksono Saputro. Penerapan Asas Keseimbangan dan Asas Kebebasan Berkontrak dalam Putusan Pengadilan, Tesis, Program Pascasarjana Magister Hukum Universitas Indonesia, 2011.

\section{Internet}

Joel Levin and Banks McDowell, "The Balance Theory of Contracts: Seeking Justice in Voluntary Obligations", Articles, sumber:http://lawjournal. mcgill.ca/userfiles/other-mcdowell.pdf, diakses pada tanggal 12/0 2020.

Negara Hukum, Prinsip Kebebasan Berkontrak Terbatas, https://www. Negara hukum. com/ hukum/prinsip-kebebasan-berkontrak-terbatas.html, diakses pada tanggal 7/2/2020

Sinta, Kajian Teoritik Kontrak Baku, https://sinta. unud.ac.id/uploads/ dokumen_dir/28b180 cebdadda3a7ae54c3df73da611.pdf, diakses pada tanggal 9/2/2020 